\title{
Cellular Distribution of Insulin-degrading Enzyme Gene Expression Comparison with Insulin and Insulin-like Growth Factor Receptors
}

\author{
Carolyn A. Bondy, Jian Zhou, Edward Chin, Rickey R. Reinhardt, Li Ding, * and Richard A. Roth * \\ Developmental Endocrinology Branch, National Institute of Child Health and Human Development, National Institutes of Health, \\ Bethesda, Maryland 20892; and *Department of Molecular Pharmacology, Stanford University, Stanford, California 94305
}

\begin{abstract}
Insulin-degrading enzyme (IDE) hydrolyzes both insulin and IGFs and has been proposed to play a role in signal termination after binding of these peptides to their receptors. In situ hybridization was used to investigate the cellular distribution of IDE mRNA and to compare it with insulin receptor (IR) and IGF-I receptor (IGFR) gene expression in serial thin sections from a variety of tissues in embryonic and adult rats. IDE mRNA is highly abundant in kidney and liver, tissues known to play a role in insulin degradation. IDE and IR mRNAs are highly coexpressed in brown fat and liver. The highest level IDE gene expression, on a per cell basis, is found in germinal epithelium. IDE and IGFR mRNAs are colocalized in oocytes, while IDE is colocalized with the IGF-II receptor in spermatocytes, suggesting that IDE may be involved with degradation of IGF-II in the testis. In summary, IDE expression demonstrates significant anatomical correlation with insulin / IGF receptors. These data are compatible with a role for IDE in degrading insulin and IGFs after they bind to and are internalized with their respective receptors and may also suggest a novel role for IDE in germ cells. (J. Clin. Invest. 1994. 93:966-973.) Key words: proteolysis • in situ hybridization • spermatocyte • oocyte • mRNA
\end{abstract}

\section{Introduction}

Proteases play a variety of roles in many physiological processes, such as complement activation and hormone processing $(1,2)$. The latter process may, in the case of some hormones, be required to generate the active hormone molecule. For example, the conversion of the inactive proinsulin to the active mature insulin requires the function of several specific proteases (3). In addition, the proteolytic cleavage of most hormones is required to terminate the response of a cell to a particular hormone. Unlike receptors, which are usually specific for a single hormone molecule, proteases often cleave multiple different molecules and several proteases can often cleave the same substrate. For example, neutral endopeptidase (or enkephalinase) has been reported to proteolyze $>24$ different hormones (4). Thus, it is often difficult to attribute to a specific protease a role in the termination of a cell's response to a particular hormone.

Insulin degradation has been extensively studied in many different cell types and tissues (5). After binding to its specific

Address correspondence to Dr. Carolyn A. Bondy, Developmental Endocrinology Branch, NICHD, Building 10, Room 10N262, National Institutes of Health, Bethesda, MD 20892.

Received for publication 17 September 1993 and in revised form 29 October 1993.

The Journal of Clinical Investigation, Inc.

Volume 93. March 1994, 966-973 receptor, insulin is internalized and degraded. The exact site and mechanism of this degradation are still not completely understood. One enzyme that has been proposed to play a role in this degradation process is called insulin-degrading enzyme (IDE). ${ }^{1}$ This enzyme has been implicated in the degradation process by the following lines of evidence. (a) Mice with elevated levels of the enzyme in the liver were more resistant to elevated levels of insulin than control mice $(6) ;(b)$ inhibitors of the enzyme in vitro also inhibit insulin degradation in intact cells $(7,8) ;(c)$ the in vitro cleavage products of insulin by IDE are in good agreement with the degradation products of insulin observed in intact cells $(5,9-11) ;(d)$ microinjection of antibodies to IDE into intact cells partially inhibited the degradation of insulin by these cells (12); $(e)$ IDE can be crosslinked to insulin in intact cells (13); and $(f)$ overexpression of IDE has been found to increase the rate of insulin degradation by cells (14).

However, IDE may also have other roles. In addition to insulin, IDE readily degrades IGF-II and to a lesser extent IGFI (15-17), glucagon (18), TGF- $\alpha$ (19), oxidatively damaged hemoglobin (20), and atrial natriuretic factor (21). To further elucidate the possible functions of this enzyme and to evaluate its anatomical correlation with sites of insulin and IGF action and presumably also hydrolysis, this study was undertaken to localize the mRNAs encoding IDE, insulin, and IGF-I receptors (IGF) in serial sections by in situ hybridization. Prior studies have analyzed the levels of IDE protein by enzyme assays (22), crosslinking with labeled insulin (23), radioimmunoassays (24), and immunocytochemical localization (25). The localization of IDE $\mathrm{mRNA}$ has previously been investigated by Northern blot analyses and by ribonuclease protection assay $(25,26)$. These studies have shown that IDE is expressed in multiple tissues. However, all of these approaches have the disadvantage that only selected tissues were examined and that cellular localization and distribution with respect to insulin and IGF receptor expression remained unknown.

\section{Methods}

Tissue. Sprague-Dawley rats were obtained from Taconic Farms (Germantown, NY) and were used in a protocol approved by the NICHD Animal Use Committee. Most tissues were obtained from adult male rats $(\sim 300 \mathrm{~g})$ but timed-pregnant females were obtained for the evaluation of embryos at embryonic day 20 (E20). Ovaries were also obtained from the dams and from juvenile females. Rats were decapitated after carbon dioxide anesthesia and tissues removed and immediately frozen over dry ice before sectioning at a thickness of $10 \mu \mathrm{m}$. Frozen sections were thaw-mounted onto poly-L-lysine-coated slides and stored at $-70^{\circ}$ until use.

1. Abbreviations used in this paper: IDE, insulin-degrading enzyme; IR, insulin receptor. 


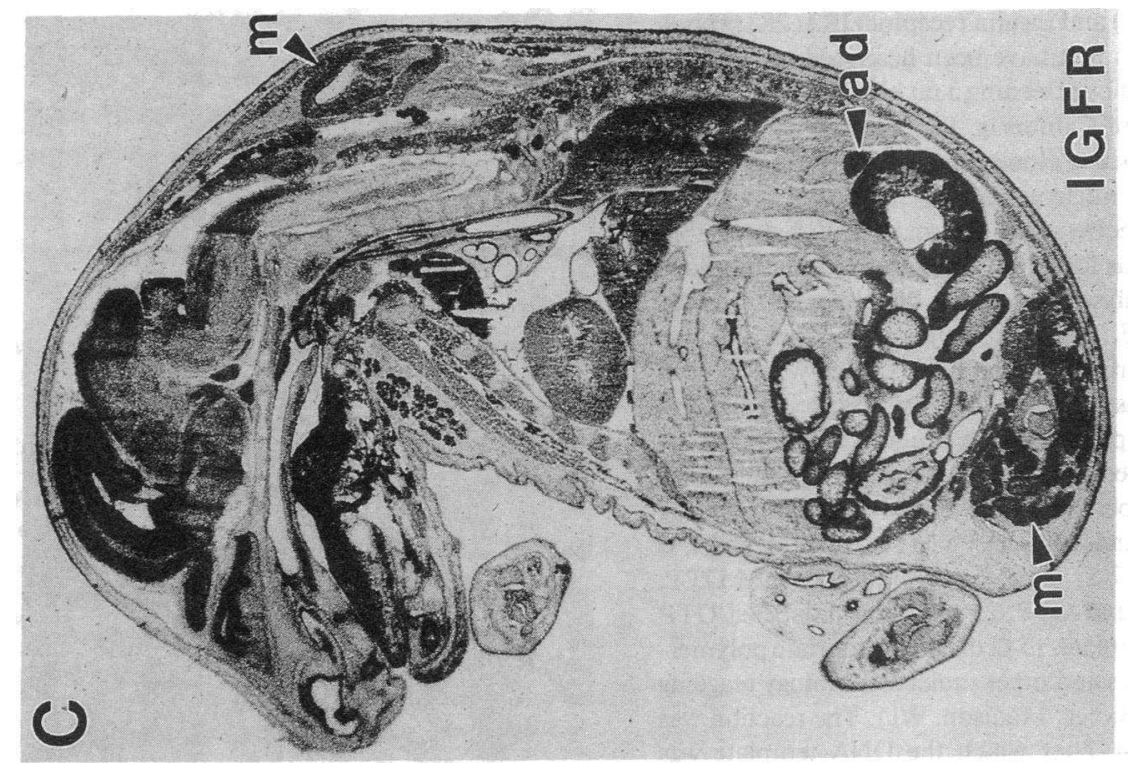

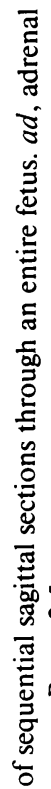

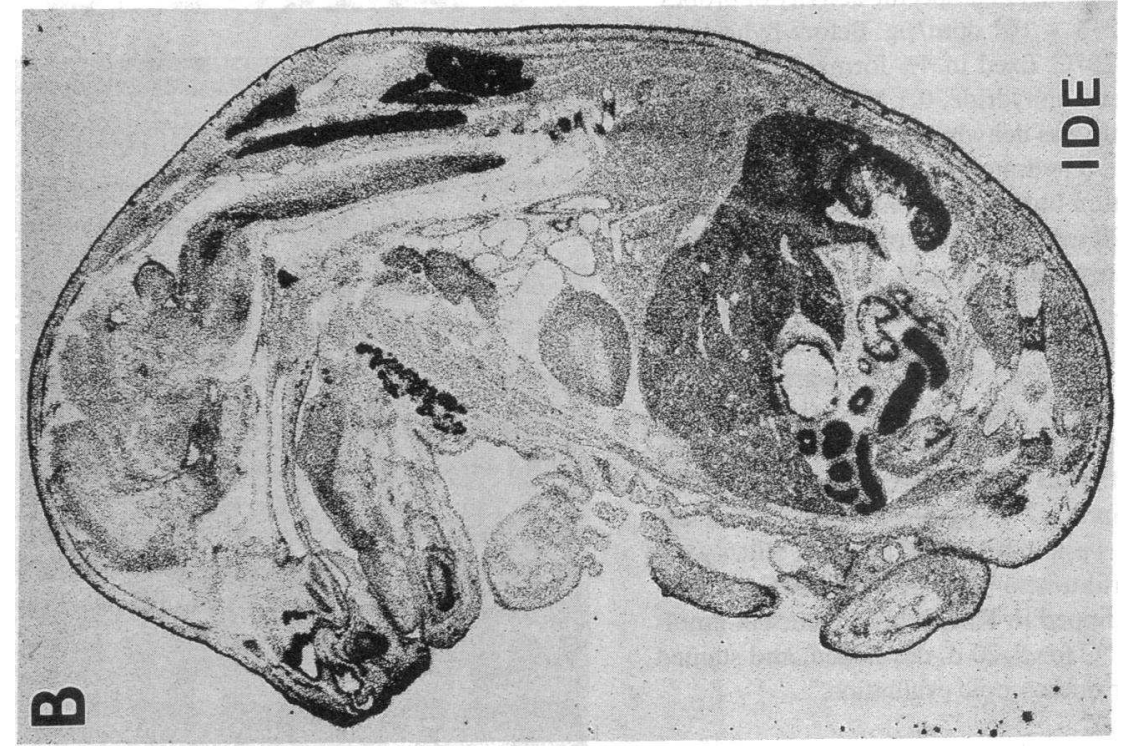

미

夏

产

ํㅜㄴ

틀

o क

I

它总

के

폰

율

要三

旨

롱

है

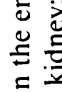

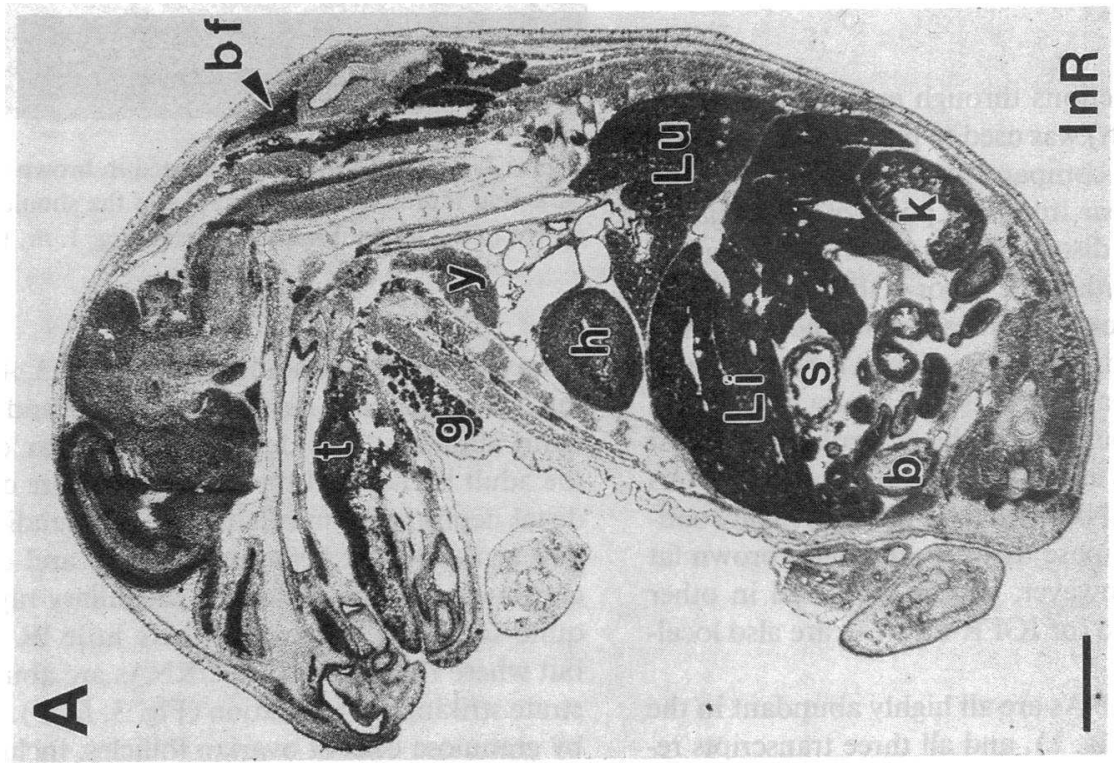

$\stackrel{x}{\underline{E}}$

产

x

峁

$\propto$ का

岕

可

岂

$\cong$

흥

5

棓泀

$\div:$

芒芒 
Preparation of RNA probes and in situ hybridization. The IGFR, IGF-II, and IGF-II receptor (27) and insulin receptor (IR) (28) probes were generated from constructs that have been described previously. The rat IDE probe was obtained by screening a rat kidney library (a gift of Dr. W. Rutter, University of California, San Francisco) with the human IDE cDNA (29). A positive clone containing $1.2 \mathrm{~kb}$ of the rat IDE cDNA (corresponding to nucleotides $400-1600$ of human IDE cDNA) was identified. The sequence of approximately half of this clone was determined and it was found to be identical to that recently reported (26). In Northern analyses, this cDNA only hybridized to the mRNA corresponding to IDE. The EcoRI fragment from this rat cDNA was inserted into Bluescript such that linearization with BamHI and use of T3 RNA polymerase yielded antisense transcription. The synthesis of ${ }^{35} \mathrm{~S}$-labeled cRNA probes and in situ hybridization protocol has been previously described $(27,28)$. In brief, high specific activity, double-labeled cRNA probes were synthesized in $10-\mu l$ reactions containing $100 \mu \mathrm{Ci}{ }^{35} \mathrm{~S}-\mathrm{CTP}$ and $100 \mu \mathrm{Ci}{ }^{35} \mathrm{~S}-\mathrm{UTP}, 10 \mathrm{mM} \mathrm{NaCl}, 6$ $\mathrm{mM} \mathrm{MgCl}$, $40 \mathrm{mM}$ Tris ( $\mathrm{pH} \mathrm{7.5),} 2 \mathrm{mM}$ spermidine, $10 \mathrm{mM}$ DTT, $500 \mu \mathrm{M}$ each unlabeled ATP and GTP, $25 \mu \mathrm{M}$ each unlabeled UTP and CTP, $500 \mathrm{ng}$ linearized template, $15 \mathrm{U}$ of the appropriate polymerase, and $15 \mathrm{U}$ RNasin (enzymes and other molecular biology reagents were obtained from Promega Biotec, Madison, WI). The reaction was incubated at $42^{\circ} \mathrm{C}$ for $60 \mathrm{~min}$, after which the DNA template was removed by digestion with DNase I. Average specific activity of probes generated in this protocol was $2-3 \times 10^{8} \mathrm{dpm} / \mu \mathrm{g}$. Before hybridization, sections were warmed to $25^{\circ} \mathrm{C}$, fixed in $4 \%$ formaldehyde, and soaked for $10 \mathrm{~min}$ in $0.25 \%$ acetic anhydride, $0.1 \mathrm{M}$ triethanolamine hydrochloride, $0.9 \% \mathrm{NaCl}$. Tissue was dehydrated through an ethanol series, delipidated in chloroform, rehydrated, and air dried. ${ }^{35}$ S-labeled probes were added to hybridization buffer $\left(10^{7} \mathrm{cpm} / \mathrm{ml}\right)$ composed of $50 \%$ formamide, $0.3 \mathrm{M} \mathrm{NaCl}, 20 \mathrm{mM}$ Tris $\mathrm{HCl}, \mathrm{pH} 8,5 \mathrm{mM}$ EDTA, $500 \mu \mathrm{g} \mathrm{tRNA} / \mathrm{ml}, 10 \%$ dextran sulfate, $10 \mathrm{mM}$ dithiothreitol, and $0.02 \%$ each of BSA, ficoll, and polyvinylpyrollidone. Hybridization buffer was added to slides that were coverslipped and placed in humidified chambers overnight $(14 \mathrm{~h})$ at $55^{\circ} \mathrm{C}$. Slides were washed several times in $4 \times$ SSC to remove cover slips and hybridization buffer, dehydrated, and immersed in $0.3 \mathrm{M} \mathrm{NaCl}, 50 \%$ formamide, $20 \mathrm{mM}$ Tris $\mathrm{HCl}, 1 \mathrm{mM}$ EDTA at $60^{\circ} \mathrm{C}$ for $15 \mathrm{~min}$. Sections were then treated with RNase A $(20 \mu \mathrm{g} / \mathrm{ml})$ for $30 \mathrm{~min}$ at $37^{\circ} \mathrm{C}$, passed through graded salt solutions, followed by a 15 -min wash in $0.1 \times \mathrm{SSC}$ at $50^{\circ} \mathrm{C}$. Slides were air dried and apposed to Hyperfilm-beta Max (Amersham Corp., Arlington Heights, IL) and then dipped in Kodak NTB2 nuclear emulsion, stored with desiccant at $4^{\circ} \mathrm{C}$ for $5-20 \mathrm{~d}$, developed, and stained with hematoxylin and eosin for microscopic evaluation.

\section{Results}

Hybridization of sagittal sections through entire rat embryos (E20, just $\sim 1 \mathrm{~d}$ before birth) was used to provide an overview or global perspective of IDE compared with IR and IGFR gene expression (Fig. 1). It is clear from this point of view that all three transcripts are widely distributed, and that there are virtually no tissues in which either the IR or IGFR and IDE are not represented. There are some significant differences in tissue distribution between IR and IGFR. IR mRNA is highly abundant in liver and fat whereas IGFR is minimally detected in these tissues and is more abundant in the musculoskeletal system; both receptor mRNAs are quite abundant in the nervous system and bowel. IDE mRNA is, like IR mRNA, highly concentrated in hepatic and adipose tissue, particularly brown fat (Figs. $1 B$ and 2 ). It is, however, widely expressed in other tissues as well, where IR and/or IGFR mRNAs are also localized.

IR, IDE, and IGFR mRNAs are all highly abundant in the fetal adrenal and kidney (Fig. 1), and all three transcripts re-
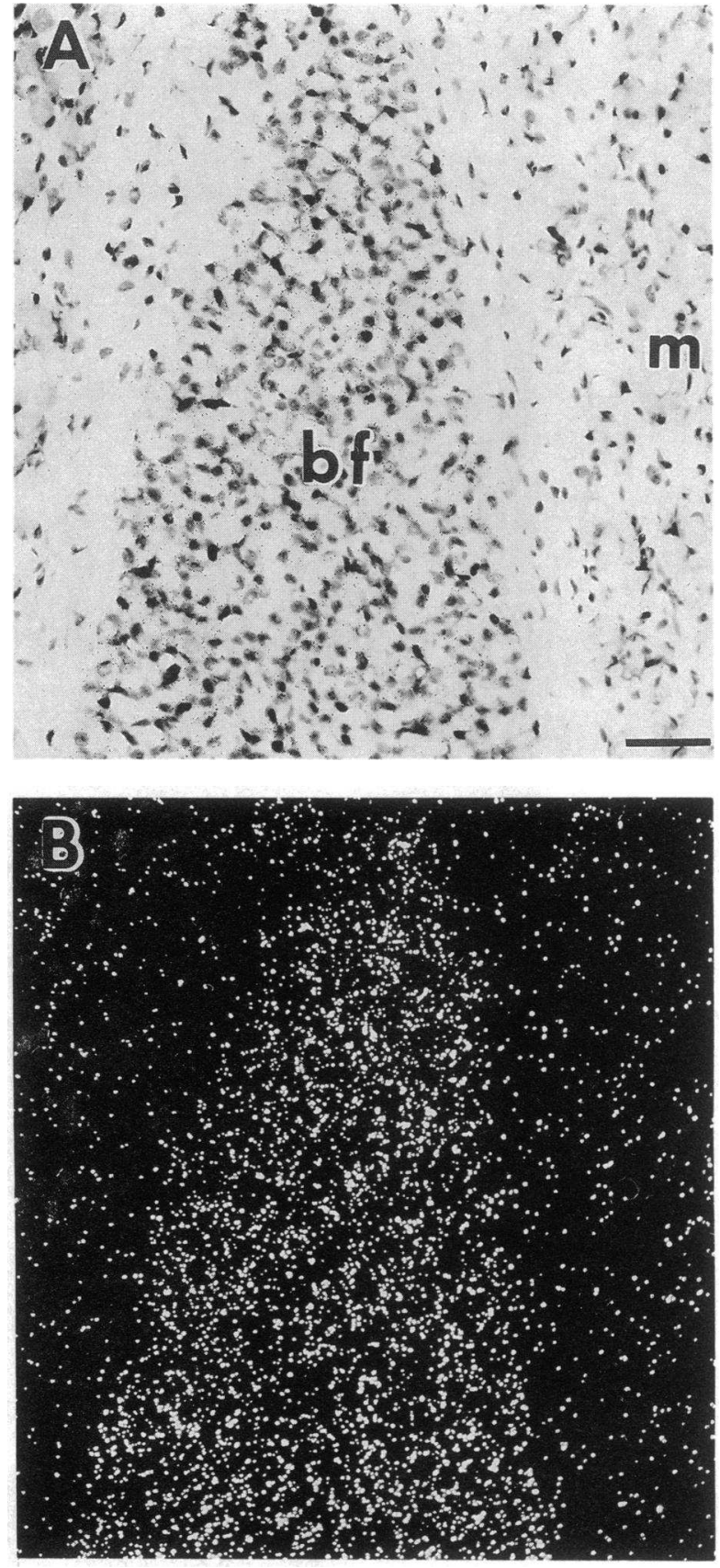

Figure 2. IDE mRNA is concentrated in brown fat $(b f)$. Bright- and dark-field illuminated micrographs of the shoulder girdle region shown in the film autoradiographs in Fig. 1. $m$, muscle. Bar $=50 \mu$.

main elevated in the adult adrenal (Fig. $3, A-C$ ). However, IR mRNA is relatively reduced while IDE and IGFR mRNAs remain abundant and demonstrate similar distribution within the adult kidney. All these transcripts are concentrated in the distal nephron, primarily the thick ascending limb, which begins at the border between the inner and outer medulla, and continues into the cortex via medullary rays. The situation is quite similar in the ovary, where little IR mRNA is detected but where IDE and IGFR mRNAs are abundant and demonstrate striking colocalization (Fig. 3, D-F). Both are expressed by granulosa cells of ovarian follicles, including the preovula- 

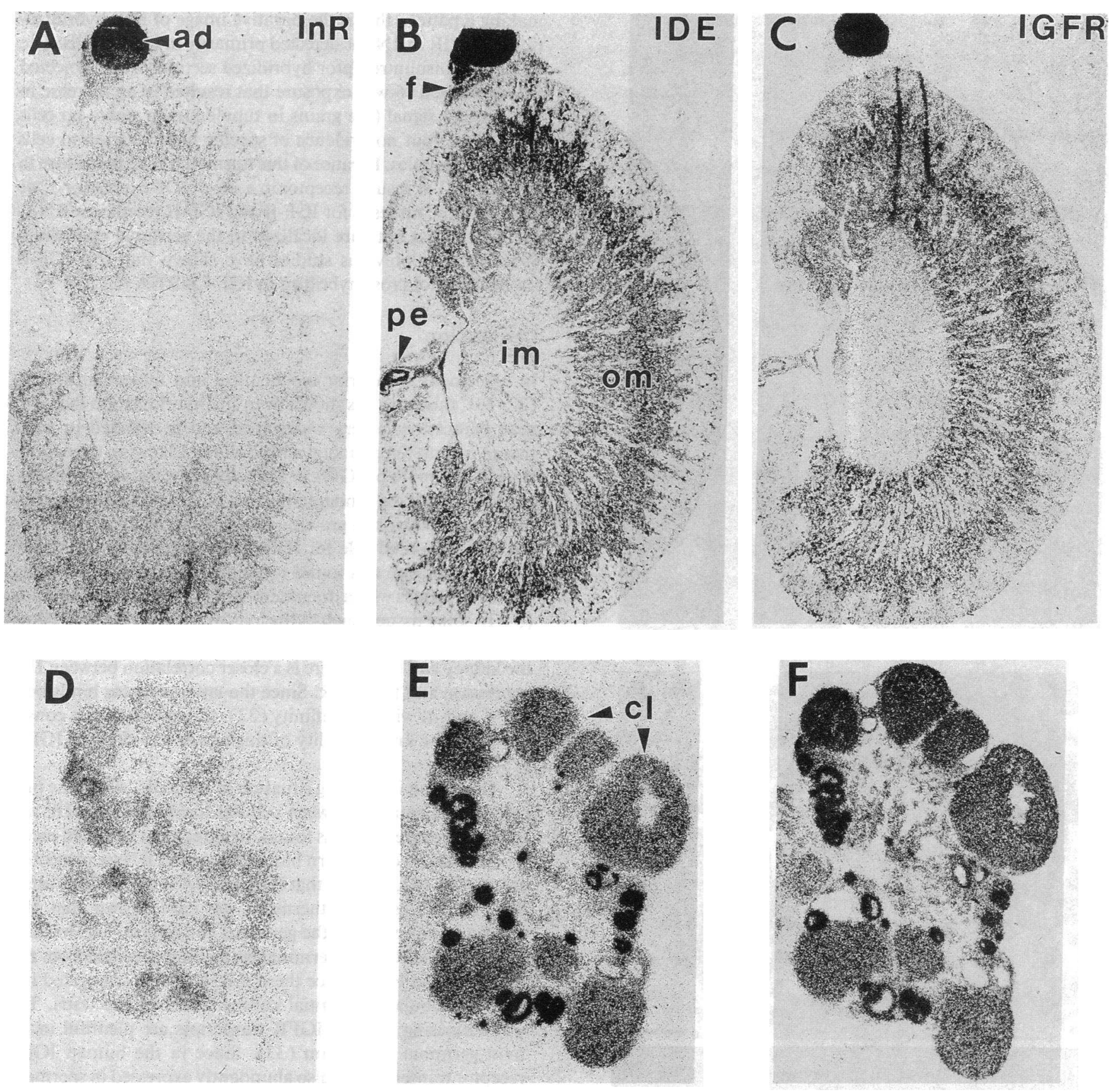

Figure 3. IDE tracks IGFR gene expression in the kidney $(A-C)$ and ovary $(D-F)$. Sequential sections were hybridized to RNA probes for IR $(A$ and $D$ ) IDE ( $B$ and $E$ ), and IGFR ( $C$ and $F$ ) and hybridization patterns are shown in film autoradiographs. $a d$, adrenal; $c l$, corpus luteum; $f$, fat; im, inner medulla; om, outer medulla; $p e$, pelvic epithelium.

tory and luteinized follicles. Most strikingly, IDE mRNA is highly abundant in oocytes (Fig. 4), as we have previously shown for IGFR, in both rodent and human ovaries $(30,31)$.

Of all tissues examined, IDE mRNA is most abundant in the mature testis, where film exposure of just several hours was sufficient to obtain the signal shown in Fig. $5 \mathrm{D}$. Little IR mRNA is detected in the testis (except for the epididymis), while IGFR mRNA is moderately abundant here (Fig. 5, $A$ and $G)$. Close inspection of the film autoradiographs shown in Fig. 5 reveals a subtle difference in testicular IDE and IGFR hybridization patterns, where the tubular pattern of IDE signal is more heterogenous and exhibits a narrower bore than the
IGFR signal. Evaluation of hybridization patterns at the microscopic level shows that IDE mRNA is concentrated in the germinal epithelium filling the lumen of the seminiferous tubules. The IDE signal is so intense and diffuse within the tubule lumen that it is impossible to say whether there is specific hybridization in Sertoli cells in addition to spermatocytes, however, in tubule segments where there is a low level of spermatogenesis, there is a proportionately low level of IDE mRNA, and no evidence of selective concentration in the Sertoli cells. In contrast, IGFR and IR mRNAs are detected exclusively in the interstitial compartment of the testis (Fig. 5, $E-I$ ). IGFR mRNA is localized in peritubular, interstitial, and Leydig cells, 

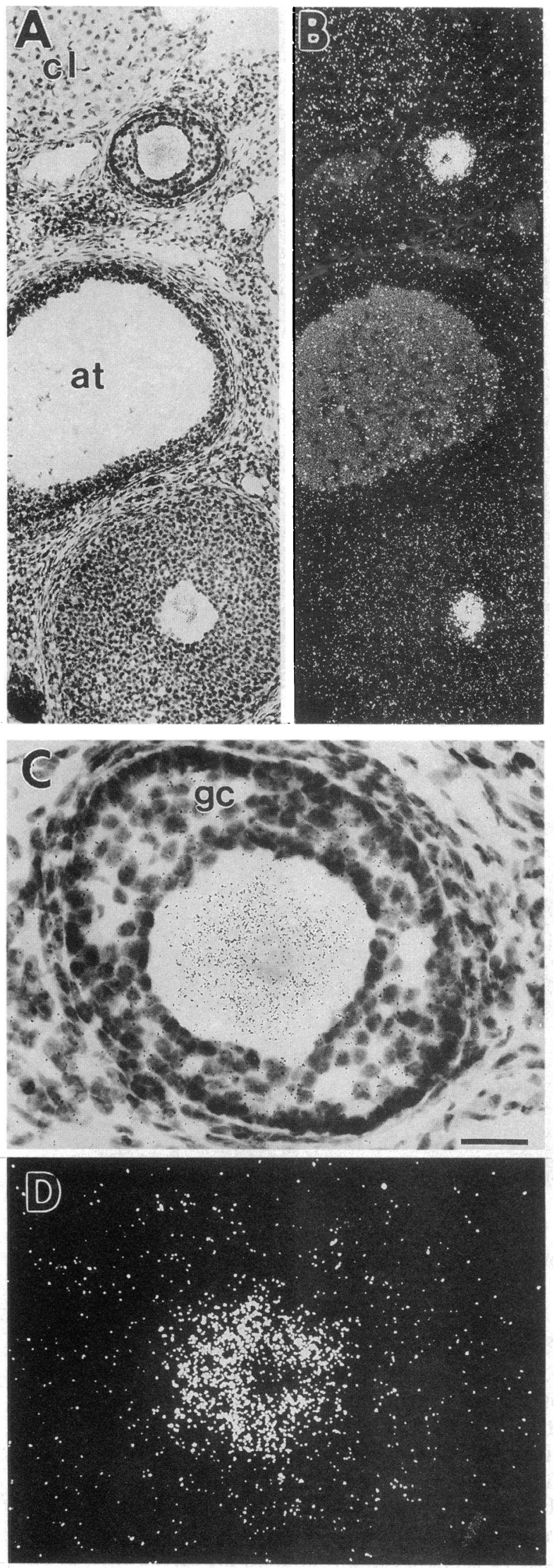

Figure 4. IDE mRNA is extremely abundant in oocytes. ( $A$ and $B$ ) Low-magnification, paired bright- and dark-field micrographs from an adult rat ovary; and ( $C$ and $D)$ high-magnification micrograph of making a pattern that is the negative image of IDE hybridization, while IR mRNA is detected primarily in Leydig cells. The IGF-I and insulin receptor hybridized sections were subjected to a prolonged (6-wk) exposure that resulted in an increase in background signal (see grains in tubule lumen where no cells are present) but no evidence of specific hybridization to cells within the tubules. Because of this mismatch (i.e., the failure to detect IGF-I or insulin receptor in a site of IDE expression), we evaluated the rat testis for IGF-II and IGF-II receptor mRNAs and found that both are localized in the germinal epithelium (Fig. 6). Our previous studies have shown that this IGF-II probe does not cross-hybridize to IGF-I mRNA (27).

\section{Discussion}

In agreement with prior biochemical and molecular studies (22-26), this work has shown by in situ hybridization that IDE gene expression is very widespread and is detected in most tissues in both the perinatal and adult rat. Likewise, the expression of either IR or IGFR is virtually universal in rat tissues, consistent with the fundamental role of these hormones in cellular metabolism and growth. The current data are consistent with the proposed role for IDE in the degradation of insulin (5). The enzyme was found to be particularly high in kidney and liver, tissues with a documented role in insulin degradation (5). In some tissues, such as the liver and brown fat, IDE parallels IR disposition very closely, whereas in other sites, such as the kidney and ovary, there is a closer correlation between IDE expression and the IGFR. Since the latter receptor binds both IGF-I and -II with high affinity (32), this correlation is consistent with the known ability of this enzyme to degrade IGF-II (15-17).

There is an interesting situation in the testis, where the only case of a mismatch between cellular localization of IDE and IR/IGFR expression was found. In agreement with two recent reports that used Northern blot analyses and RNase protection assays $(25,26)$, we find that IDE mRNA is particularly abundant in the testis. Furthermore, we have shown that IDE mRNA is expressed by the germinal epithelium. The localization of IDE mRNA in germinal epithelium diverged from that of the IR and IGFR since these mRNAs were segregated into the extratubular, interstitial compartment of the testis. This was surprising because IGFR transcripts are plentiful in human germinal epithelium (33). Since in the human IGF-II receptor transcripts are also abundantly expressed in spermatogenic epithelium (33), we investigated IGF-II and IGF-II receptor gene expression in the rat testis and found that both transcripts were localized in germinal epithelium, consistent with a role for IDE in IGF-II degradation. A previous study reported that the IGF-II (cation-independent mannose-6-phosphate) receptor is synthesized in cultured murine spermatocytes, although it appears more abundant in cultured immature Sertoli cells (34).

The high level of IDE gene expression in gonads supports the view that IGFs have major roles in regulation of reproductive function, in particular germ cell growth and maturation.

a single follicle with an IDE-expressing oocyte. The large, pale-staining nucleus is faintly visible in the center of the oocyte. at, atretic follicle; $g c$, granulosa cells; $c l$, corpus luteum. Bar $=100 \mu \mathrm{m}$ for $A$ and $B$ and $20 \mu \mathrm{m}$ for $C$ and $D$. 

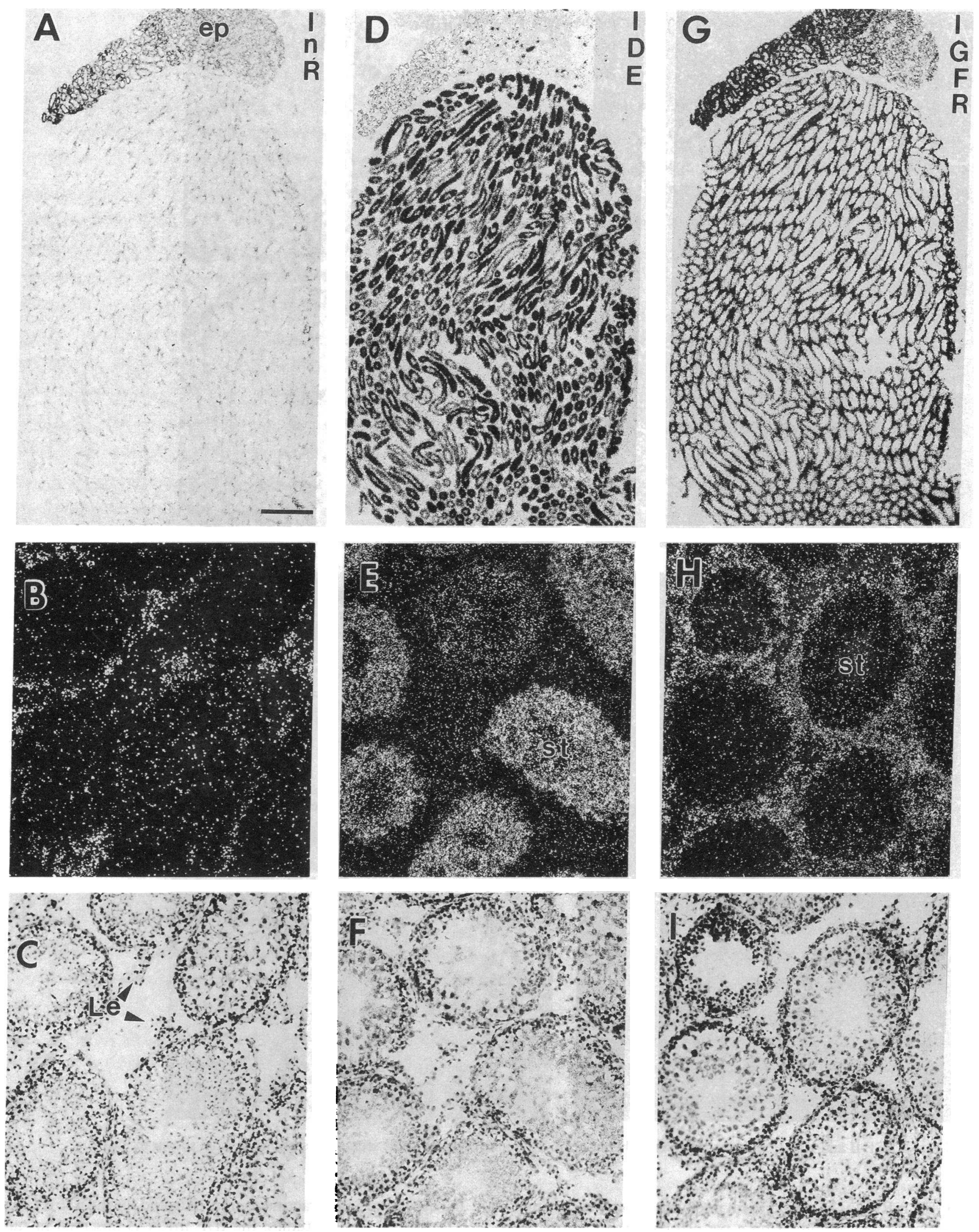

Figure 5. Comparison between IR $(A-C)$, IDE $(D-F)$, and IGFR $(G-I)$ gene expression in the rat testis. $(A, D$, and $G)$ Film autoradiographs of sequential sections that were exposed for $6 \mathrm{~d}, 6 \mathrm{~h}$, and $4 \mathrm{~d}$, respectively. $(B-I)$ Paired bright- and dark-field autoradiographs showing hybridization in cross-sectional views of seminiferous tubles. $e p$, epididymis: $L e$, Leydig cells; $s t$, seminiferous tubule. Bar $=1.5 \mathrm{~mm}$ for $A-C$ and 100 $\mu \mathrm{m}$ for $B-I$. 

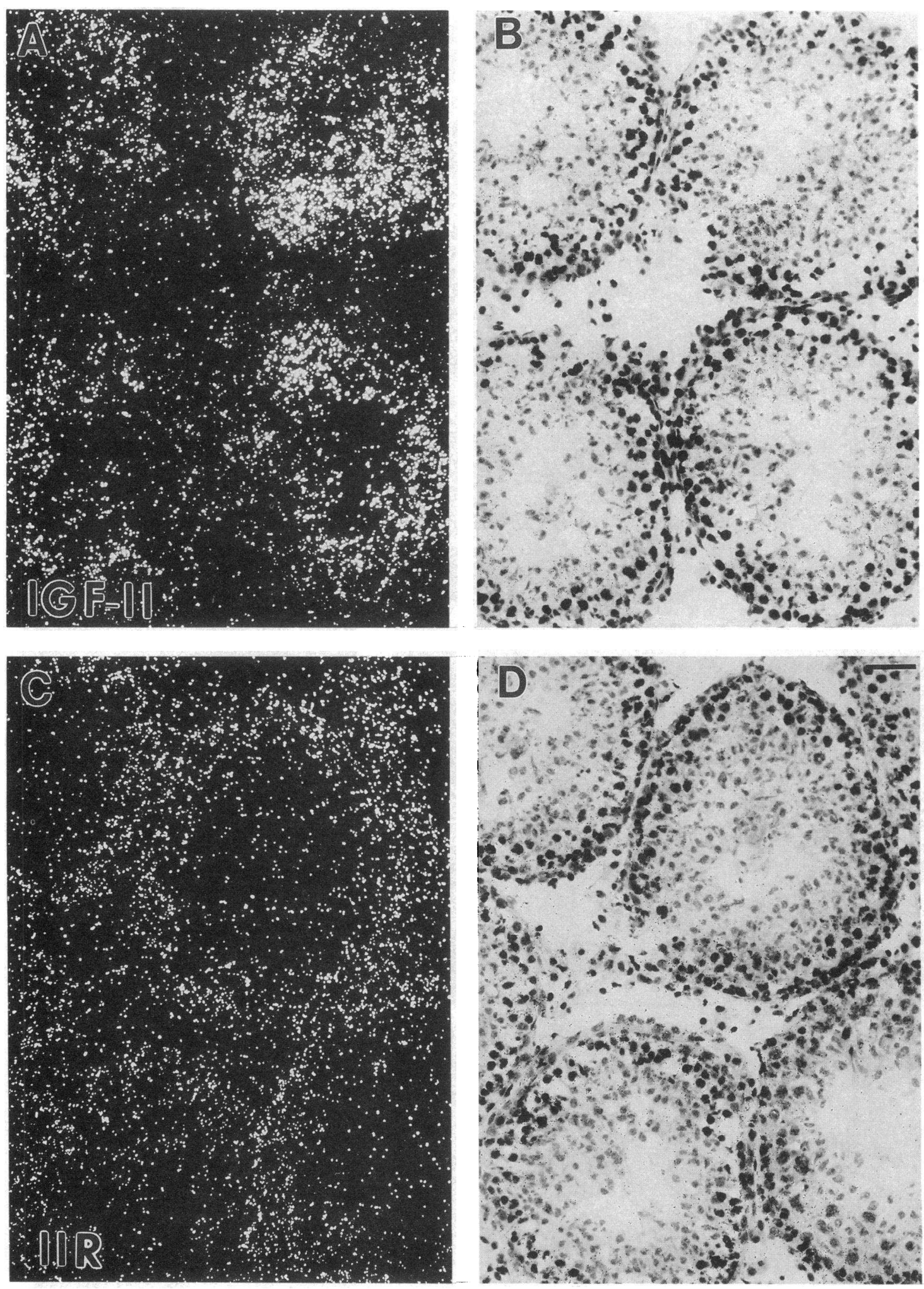

Figure 6. IGF-II and IGF-II receptor mRNAs in the rat testis. These micrographs show sequential sections to those shown in Fig. 5.

IGFR mRNA is localized in rat and human oocytes, where it is perhaps more abundant on a per cell basis than in any other cell type, $(30,31)$ and is also expressed in human spermatocytes (33). In the human ovary, IGF-II mRNA is localized in oocytes themselves and in granulosa cells that form the follicle supporting oocyte development, providing evidence for poten- tial autocrine and paracrine sources of ligand for the IGFR ( 30 , 31 ). In two recent studies, the IDE mRNAs observed in rat testis by Northern analyses were slightly larger than in other tissues $(25,26)$, suggesting that this mRNA might encode a distinct isoenzyme of IDE preferentially expressed in germ cells. This finding, coupled with the extraordinary abundance 
of IDE transcripts in germ cells, which seems somewhat out of proportion to the level of receptor expression when compared with their relative expression levels in other cell types, raises the possibility that IDE may have an alternate function in germ cells. For example, metallo-endoproteases have been implicated in sperm-egg fusion (35).

In summary, IDE and the receptors for the insulin/IGF family of hormones share a common distribution, supporting the possibility that IDE plays a physiological role in the degradation of insulin and IGFs. IDE also has proteolytic activity against glucagon, atrial natriuretic factor, and TGF $\alpha(18-21)$. In general, however, these factors each display a narrower spectrum of action and receptor distribution than the insulin/IGF family, so the present data showing the widespread distribution of IDE mRNA do not support any selective association between IDE and these other peptides. The possibility must also be considered that IDE has a fundamental role in cellular physiology, which is virtually universal but not specifically related to degradation of insulin or IGF peptides.

\section{Acknowledgments}

We thank Drs. Bill Rutter and Jeff Edman for the rat kidney library and Ricardo Dreyfuss for expert photomicrography. This work was supported by National Institutes of Health grant DK-34926.

\section{References}

1. Barrett, A. J. 1992. Cellular proteolysis, an overview. Ann. NY Acad. Sci. 674:1-15.

2. Bond, J. S., and P. E. Butler. 1987. Intracellular Proteases. Ann. Rev. Biochem. 56:333-364.

3. Steiner, D. F., S. P. Smeekens, S. Ohagi, and S. J. Chan. 1992. The new enzymology of precursor processing endoproteases. J. Biol. Chem. 267:2343523438.

4. Erdos, E. G., and R. A. Skidgel. 1989. Neural endopeptidase 24.11 (enkephalinase) and related regulators of peptide hormones. FASEB (Fed. Am. Soc. Exp. Biol.) J. 3:145-151.

5. Duckworth, W. C. 1988. Insulin degradation: mechanisms, products, and significance. Endocr. Rev. 9:319-345.

6. Beyer, R. E. 1955. A study of insulin metabolism in an insulin tolerant strain of mice. Acta Endocrinol. 19:309-332.

7. Kayalar, C., and W. T. Wong. 1989. Metalloendoprotease inhibitors which block the differentiation of $\mathrm{L} 6$ myoblasts inhibit insulin degradation by the endogenous insulin-degrading enzyme. J. Biol. Chem. 264:8928-8934.

8. Harada, S., R. M. Smith, J. A. Smith, and L. Jarett. 1993. Inhibition of insulin-degrading enzyme increases translocation of insulin to the nucleus in $\mathrm{H} 35$ rat hepatoma cells: Evidence of a cytosolic pathway. Endocrinology. 132:22932298.

9. Assoian, R. K., and H. S. Tager. 1981. Peptide intermediates in the cellular metabolism of insulin. J. Biol. Chem. 257:9078-9085.

10. Hamel, F. G., M. J. Mahone, and W. C. Duckworth. 1991. Degradation of intraendosomal insulin by insulin-degrading enzyme without acidification. Diabetes. $40: 436-443$.

11. Williams, F. G., D. E. Johnson, and G. E. Bauer. 1990. [ $\left.{ }^{125} I\right]-$ Insulin metabolism by the rat liver in vivo: evidence that a neutral thiol-protease mediates rapid intracellular insulin degradation. Metab. Clin. Exp. 39:231-241.

12. Shii, K., and R. A. Roth. 1986. Inhibition of insulin degradation by hepatoma cells after microinjection of monoclonal antibodies to a specific cytosolic protease. Proc. Natl. Acad. Sci. USA. 83:4147-4151.

13. Hari, J., K. Shii, and R. A. Roth. 1987. In vivo association of ${ }^{125} \mathrm{I}$-insulin with a cytosolic insulin-degrading enzyme: Detection by covalent cross-linking and immunoprecipitation with a monoclonal antibody. Endocrinology. 120:829831 .

14. Kuo, W.-L., B. D. Gehm, and M. R. Rosner. 1991. Regulation of insulin degradation: expression of an evolutionarily conserved insulin-degrading enzyme increases degradation via an intracellular pathway. Mol. Endocrinol. 5:14671476.

15. Roth, R. A., M. L. Mesirow, K. Yokono, and S. Baba. 1984. Degradation of insulin-like growth factors I and II by a human insulin degrading enzyme. Endocr. Res. 10:101-112.

16. Misbin, R. I., E. C. Almira, W. C. Duckworth, and T. Mehl. 1983. Inhibition of insulin degradation by insulin-like growth factors. Endocrinology. 113:1525-1527.

17. Misbin, R. I., and E. C. Almira. 1989. Degradation of insulin and insulinlike growth factors by enzyme purified from human erythrocytes; Comparison of degradation products observed with A14- and B26[ $\left.{ }^{125}\right]$ monoiodoinsulin. Diabetes. 38:152-158.

18. Kirschner, R. J., and A. L. Goldberg. 1983. A high molecular weight metalloenoprotease from the cytosol of mammalian cells. J. Biol. Chem. 258:967-976.

19. Gehm, B. D., and M. R. Rosner. 1991. Regulation of insulin, epidermal growth factor, and transforming growth factor-alpha levels by growth factor-degrading enzymes. Endocrinology. 128:1603-1610.

20. Fagan, J. M., and L. Waxman. 1991. Purification of a protease in red blood cells that degrades oxidatively damaged haemoglobin. Biochem. J. 277:779-786.

21. Muller, D., H. Baumeister, F. Buck, and D. Richter. 1991. Atrial natriuretic peptide (ANP) is a high-affinity substrate for rat insulin-degrading enzyme. Eur. J. Biochem. 202:285-292.

22. Phelps, B. H., P. T. Varandani, and L. A. Shroyer. 1979. Insulin B chaindegrading neutral peptidase activity in the rat. Tissue distribution and the effects of starvation and streptozotocin-induced diabetes. Arch. Biochem. Biophys. 195:1-11.

23. Shii, K., S. Baba, K. Yokono, and R. A. Roth. 1985. Covalent linkage of ${ }^{125}$ I-insulin to a cytosolic insulin-degrading enzyme. J. Biol. Chem. 260:65036506.

24. Akiyama, H., K. Yokono, K. Shii, W. Ogawa, H. Taniguchi, S. Baba, and M. Kasuga. 1990. Natural regulatory mechanisms of insulin degradation by insulin degrading enzyme. Biochem. Biophys. Res. Commun. 170:1325-1330.

25. Kuo, W.-L., A. G. Montag, and M. R. Rosner. 1993. Insulin-degrading enzyme is differentially expressed and developmentally regulated in various rat tissues. Endocrinology. 132:604-611.

26. Baumeister, H., D. Muller, M. Rehbein, and D. Richter. 1993. The rat insulin-degrading enzyme: molecular cloning and characterization of tissue-specific transcripts. FEBS (Fed. Eur. Biochem. Soc.) Lett. 317:250-254.

27. Zhou, J., and C. A. Bondy. 1992. IGF-II and its binding proteins in the placenta. Endocrinology. 131:1230-1240.

28. Bondy, C. A., M. A. Bach, and W. H. Lee. 1992. Mapping of brain insulin and insulin-like growth factor gene expression in in situ hybridization. Neuroprotocols. 1:240-249.

29. Af fholter, J. A., V. A. Fried, and R. A. Roth. 1988. Human insulin-degrading enzyme shares structural and functional homologies with $\mathrm{E}$. coli protease III. Science (Wash. DC). 242:1415-1418.

30. Zhou, J., E. Chin, and C. A. Bondy. 1991. Cellular pattern of IGF-1 and IGF-1 receptor gene expression in the developing and mature follicle. Endocrinology. 129:3281-3288.

31. Zhou, J., and C. A. Bondy. 1993. Anatomy of the human ovarian IGF system. Biol. Reprod. 48:467-482.

32. Roth, R. A., G. Steele-Perkins, J. Hari, C. Stover, S. Pierce, J. Turner, J. C. Edman, and W. J. Rutter, 1988. Insulin and insulin-like growth factor receptors and responses. Cold Spring Harbor Symp. Quant. Biol. LIII:537-543.

33. Zhou, J., and C. A. Bondy. 1993. Anatomy of the insulin-like growth factor system in the human testis. Fertil. Steril. 60:897-904.

34. O'Brien, D. A., C. A. Gabel, D. L. Rockett, and E. M. Eddy. 1989. Receptor-mediated endocytosis and differential synthesis of mannose-6-phosphate receptors in isolated spermatogenic and sertoli cells. Endocrinology. 125:29732984.

35. Lennarz, W. J., and W. J. Strittmaster. 1991. Cellular functions of metallo-endoproteases. Biochem. Biophys. Acta. 1071:149-158. 